\title{
Pengaruh Ukuran Perusahaan, Kompetensi, dan Sikap Auditor terhadap Audit Delay
}

\author{
Amelia Oktrivina DS \\ Program Studi Akuntansi, Fakultas Ekonomi dan Bisnis, Universitas Pancasila, Jakarta, Indonesia \\ siregaramelia379@yahoo.com
}

\begin{abstract}
This study aimed to analyze whether the size of the company, competence, and attitudes affect the auditor's audit delay. Variables used in this study include the audit delay as the dependent variable, the size of the company, competence and attitude of auditors as independent variables. Respondents who studied 32 people (respondents), which is a population of 3 KAP in the area of Jakarta (Jakarta South). Research using questionnaires and analyzed subjects are auditors. The data obtained were analyzed using the Linear Regression method. These studies suggest that the size of the company's effect on audit delay. While the competence and attitude of auditors has no effect on audit delay. Simultaneously, company size, competence and attitude affect the auditor's audit delay.
\end{abstract}

Keywords: Audit Delay, Company Size, Competence and Attitude Auditor

\begin{abstract}
Abstrak
Penelitian ini bertujuan untuk menganalisis apakah ukuran perusahaan, kompetensi, dan sikap mempengaruhi penundaan audit auditor. Variabel yang digunakan dalam penelitian ini meliputi audit delay sebagai variabel dependen, ukuran perusahaan, kompetensi dan sikap auditor sebagai variabel independen. Responden yang meneliti 32 orang (responden), yaitu populasi 3 KAP di wilayah Jakarta (Jakarta Selatan). Penelitian menggunakan kuesioner dan subyek yang dianalisis adalah auditor. Data yang diperoleh dianalisis menggunakan metode Linear Regression. Studi-studi ini menunjukkan bahwa ukuran efek perusahaan pada audit delay. Sedangkan kompetensi dan sikap auditor tidak berpengaruh pada audit delay. Secara bersamaan, ukuran perusahaan, kompetensi dan sikap mempengaruhi penundaan audit auditor.
\end{abstract}

Keywords: Audit Delay, Ukuran Perusahaan, Kompetensi dan Sikap Auditor

\section{PENDAHULUAN}

Pendahuluan memaparkan tentang latar belakang masalah, motivasi penelitian, rumusan masalah (berisi pertanyaan-pertanyaan tentang hubungan antarvariabel), dan tujuan penelitian. Pendahuluan ditulis dalam bentuk paragraf mengalir dan hindari sub-sub di dalam pendahuluan.

Semakin berkembangnya dunia usaha di Indonesia menyebabkan perusahaan-perusahaan besar membutuhkan karyawan dengan tingkat pengetahuan yang luas dan sikap pegawai yang baik sesuai etika baik itu di perusahaan yang kecil maupun besar. Sebagian dari hal tersebut dapat mempengaruhi laporan audit ke depanya. Namun permasalahan yang sering terjadi dalam audit yaitu tingkat kesiapan laporan yang akan dipublikasikan kepada publik sering sekali terjadi ketelatan atau keterlambatan yang di timbulkan akibat kurangnya persiapan dalam penyelesaian laporan maupun akibat kurangnya pengetahuan audit dalam menyelesaikan laporan sehingga laporan perlu dikoreksi lebih dari sekali.

Secara umum timbulnya permasalahan yang telah terjadi akibat resiko adanya auditor baru dan juga permasalahan bukti yang hilang atau entah kemana, sehingga publikasi audit menjadi lebih lama. Dari hal yang disebutkan biasanya seorang audit memiliki titik dimana seseorang jenuh atau frustasi. Hal ini terjadi karena dampak laporan keuangan yang terus menerus dia kerjakan tak kunjung selesai akibat bukti-bukti yang sulit didapatkan karena bukti tersebut bersifat rahasia yang hanya orang tertentu yang mengetahuinya.

Kompetensi berkaitan dengan keahlian profesional yang dimiliki auditor sebagai hasil dari pendidikan formal (menurut Ilmiyati dan Suhardjo, 2012). Hal tersebut menjelaskan bahwa tingkat pengetahuan bagi seorang auditor sangat diperlukan demi kelangsungan hidup perusahaan. Menurut 
Praptitorini dan Januarti (2007), Kelangsungan hidup usaha selalu dihubungkan dengan kemampuan manajemen dalam mengelola perusahaan agar mampu bertahan hidup selama mungkin.

Salah satu usaha untuk meminimalkan keterlambatan laporan keuangan maka di butuhkan audit yang memiliki tingkat pengetahuan yang luas tentang audit (standar audit) dan memberikan penghargaan (reword) kepada audit sehingga mengurangi sikap jenuh seorang audit dalam menyelesaikan laporan keuangan. Tingkat pengetahuan audit disesuaikan dalam pedoman GAAS (generally accepted auditing standards), yang dikembangkan AICPA dan diperbaharui dengan SAS 105 dan SAS 113. Standar pengetahuan audit secara umum berupa standar umum, standar pekerjaan lapangan, dan standar pelaporan, selama seorang audit berpegang teguh terhadap standar-standar tersebut maka audit dapat dikatagorikan sebagai audit yang memiliki kompetensi.

Tujuan laporan keuangan adalah menyediakan informasi yang menyangkut posisi keuangan, kinerja, serta perubahan posisi keuangan suatu perusahaan yang bermanfaat bagi sejumlah besar pemakaian dalam pengambilan keputusan ekonomi (IAI, 2012). Agar informasi yang disediakan bermanfaat, maka informasi tersebut harus relevan. Ketepatan waktu tidak menjamin relevansi, tetapi relevansi tidaklah mungkin tanpa ketepatan waktu. Oleh karena itu ketepatan waktu adalah batasan penting pada publikasi laporan keuangan (Hendriksendan Breda, 2000). Oleh sebab itu, penelitian ini mengangkat judul "Pengaruh Ukuran Perusahaan, Kompetensi, dan Sikap Auditor Terhadap Audit Delay".

\section{KERANGKA PENELITIAN \& HIPOTESIS}

Laporan keuangan pada dasarnya adalah hasil dari proses akuntansi yang dapat digunakan sebagai alat untuk berkomunikasi antara data keuangan atau aktivitas perusahaan dengan perusahaan-perusahaan yang berkepentingan. Menurut Baridwan (2010), laporan keuangan merupakan ringkasan dari suatu proses pencatatan, yang merupakan ringkasan dari tansaksi-tansaksi keuangan yang terjadi selama tahun buku yang bersangkutan.

Dalam Standar Akuntansi Keuangan (PSAK) Laporan Keuangan adalah :

"Laporan keuangan yang menyediakan informasi menyangkut posisi keuangan, kinerja, serta perubahan posisi keuangan perusahaan yang ditujukan untuk memenuhi kebutuhan bersama sebagaian besar pengguna laporan". (IAI, 2012)

Berdasarkan beberapa pengertian di atas dapat disimpulkan Laporan Keuangan merupakan produk akuntansi yang penting dan dapat digunakan untuk membuat keputusan-keputusan ekonomi bagi pihak internal dan eksternal (1) Merupakan potret prusahaan, yaitu dapat menggambarkan kinerja keuangan maupun kinerja manajemen perusahaan dalam setiap kondisi. (2) Merupakan rangkaian aktivitas ekonomi perusahaan yang diklasifikasikan dalam suatu periode perusahaan dalam kurun waktu setahun. (3) Merupakan ringkasan dari suatu proses transaksi-transaksi keuangan yang terjadi selama periode yang bersangkutan (4) Laporan keuangan perusahaan merupakan salah satu sumber informasi yang penting di samping informasi lain seperti informasi industri, kondisi perekonomian, pangsa perusahaan, kualitas manajemen dan lainnya. Jadi setiap perusahaan go public diwajibkan untuk mempublikasikan laporan keuangan yang disusun sesuai dengan standar akuntansi keuangan dan telah diaudit oleh Kantor Akuntansi Publik (KAP) yang telah terdaftar di Badan Pengawasan Pasar Modal (BAPEPAM).

Teori agensi (agency theory) merupakan salah satu aliran riset terpenting. Teori agensi berfokus pada biaya-biaya pemantauan dan penyelengaraan hubungan antara berbagai pihak.

Hubungan agensi muncul ketika satu orang atau lebih mempekerjakan orang lain untuk memberikan suatu jasa dan kemudian mendelegasikan wewenang pengambilan keputusan kepada agen tersebut.

Definisi audit menurut Aren, Elder, Beasley dan Jusuf (2010) menjelaskan bahwa pengertian auditing adalah: "Auditing is the accumulation and evaluation of evidence about information to determine and report on the degree of correspondence between the information and stablished criteria. Auditing should be done by a competent, independent person".

Sedangkan pengertian audit menurut Mulyadi (2002): "Suatu proses sistematis untuk mendapatkan dan mencari bukti-bukti dengan cara objektif yang berkaitan dengan pernyataan-pernyataan tentang tindakan-tindakan dan kejadian-kejadian ekonomi untuk menentukan kesesuaian antara pernyataan tersebut dengan kriteria yang telah ditetapkan dan menyampaikan hasilnya kepada pihak yang berkepentingan". Menurut Arens et al. (2010) terdapat beberapa jenis auditor yang berpraktik sekarang ini, di antaranya: Auditor Independen (Akuntansi Publik), Auditor Pemerintah, dan Auditor Internal (Internal Auditor).

Tugas dari auditor internal sangat beragam, tergantung pada tugas-tugas yang dibebankan oleh perusahaan kepada auditor. Tugas auditor internal dapat berupa audit ketaatan, audit operasional, 
evaluasi sistem komputer, dan termasuk bidang di luar akuntansi.

Standar professional akuntan publik (SPAP) Mengharuskan pembuatan laporan setiap kali kantor akuntan publik dikaitkan dengan laporan keuangan. Ikatan Akuntansi Indonesia (2011) menyatakan bahwa laporan audit harus memuat suatu pernyataan pendapat mengenai laporan keuangan secara keseluruhan atau suatu asersi bahwa pernyataan demikian tidak diberikan. Terdapat lima pendapat yang mungkin diberikan oleh akuntan publik atas laporan keuangan yang diauditnya (Mulyadi, 2005). Pendapat tersebut adalah Pendapat Wajar Tanpa Pengecualian (Unqualified Opinion), Pendapat Wajar Tanpa Pengecualian dengan Bahasa Penjelas (Unqualified Opinion Report with Explanatory Language), Wajar dengan Pengecualian (Qualified Opinion), Pendapat tidak Wajar (Adverse Opinion), dan Pernyataan Tidak Memberikan Pendapat (Disclaimer of Opinion). Menurut Lawrence dan Briyan (1988) dalam Yugo Trianto (2006:31) definisi Audit Delay adalah lamanya hari yang dibutuhkan auditor untuk menyelesaikan pekerjaan auditnya, yang diukur dari tanggal penutupan tahun buku hingga tanggal diterbitkannya laporan keuangan audit.

Perusahaan yang go public harus menyerahkan laporan keuangan tahunannya disertai dengan opini auditor kepada Bapepam. Peraturan Bapepam tersebut diatur dalam Undang-Undang No.8 tahun 1995 tentang publikasi laporan keuangan tahunan auditan yang bersifat wajib dengan batas waktu 120 hari dari akhir tahun fiskal sampai tanggal diserahkannya laporan keuangan yang telah diaudit ke BAPEPAM. Namun, Sejak 30 September 2003, peraturan ini diganti dengan peraturan baru dengan Nomor X.K.2 tentang kewajiban penyampaian laporan keuangan ke Bapepam menjadi 90 hari (Ani Yulianti, 2011:12).

Faktor-Faktor yang mempengaruhi audit delay menurut Suhardjo, 2012 yaitu Ukuran Perusahaan, Laba / Rugi Operasi, Opini / Jenis Pendapat Akuntan Publik, Tingkat Profitabilitas, Reputasi Auditor, Kualitas Audit, dan Solvabilitas Nilai aset dipilih karena nilai yang dimiliki relatif lebih stabil dibandingkan dengan prospek lain (Kristina, 2012). Namun dengan menganalisis pandangan auditor terhadap laporan keuangan dengan menentukan apakah perusahaan tersebut besar atau kecil, maka penelitian ini melihat dengan meneliti berapa sampel dari penelitian terdahulu sebagai dasar penilaian ukuran perusahaan dengan tingkat nominal yang telah diteliti oleh peneliti terdahulu. Dengan penelitian di BEI tahun 2009-2011 dibuktikannya nilai $\mathrm{p}$-value uji t kurang dari alfa 5 persen yaitu 0.0084 maka besarnya ukuran perusahaan dengan tingkat masing-masing dari laporan keuangan minimum sebesar 24,6 persen dan nilai maksimum 34,6 persen dari setiap katagori perhitungan baik itu total aset, penjualan, dan kapitalisasi pasar (Menurut Heru Setiawan, 2012). Menurut Andi Kartika, 2009 penelitian tentang ukuran perusahaan dengan menggunakan kriteria yang akan diteliti yaitu saham berada $>95 \%$ dari total rata-rata tahuan transaksi saham pasar regular dan $>90 \%$ dari rata-rata tahunan kapitalisasi pasar. Maka diketahui hasil penelitian ukuran perusahan dengan nilai t untuk variabel total asset adalah $-3,855<-\mathrm{t}(-1,997)$ dan nilai probabilitas sebesar $0,000<0,05$. Hasil tersebut memperkuat bahwa penentuan minimum sebesar 24,6 persen dan nilai maksimum 34,6 persen terhadap total aset memberitahukan besar atau kecilnya perusahaan yang akan diaudit. Untuk itu di dalam ukuran perusahaan perlu dilihat dari seberapa besar nilai entitas perusahaan. Yang terdiri atas pembagian perusahaan yaitu: perusahaan besar dan perusahaan kecil.

Dalam melakukan audit, seorang auditor harus melakukan mutu personal yang baik, pengetahuan yang memadai, serta keahlian khusus di bidangnya. Kompetensi berkaitan dengan keahlian profesional yang dimiliki oleh auditor sebagai hasil dari pendidikan formal, uji profesional maupun keikutsertaan dalam pelatihan, seminar, dan simposium (Ilmiyati dan Suhardjo, 2012).

Ada beberapa hal yang sering dituntut / dipertanyakan publik terhadap seorang auditor. Tuntutan tersebut berasal dari pernyataan yang ada pada standar umum audit baik dalam SPAP, SPKN, ataupun standar lainnya yang dimiliki Negara anggota International Organization of Supreme Audit Institutions (INTOSAI). Kompetensi auditor adalah klasifikasi yang dibutuhkan oleh auditor untuk melaksanakan audit yang benar. Untuk memeproleh kompetensi tersebut, dibutuhkan pendidikan dan pelatihan bagi auditor yang dikenal dengan nama pendidikan profesional berkelanjutan. Ada beberapa komponen dari kompetensi auditor tersebut yaitu mutu personal, pengetahuan umum, dan keahlian khusus.

\section{a. Mutu Personal}

Dalam menjalankan tugasnya, seorang auditor harus memiliki mutu personal yang baik, seperti: 1) Berpikir terbuka (open-minded), 2) Berpikir luas (board-minded), 3) Mampu menangani ketidak pastian, 4) Mampu bekerjasama dalam tim, 5) Rasa ingin tahu (inquisitive), 6) Mampu menerima bahwa tidak ada solusi yang mudah, dan 7) Menyadari bahwa beberapa temuan dapat bersifat subjektif

Di samping itu, auditor juga harus memiliki kemampuan komunikasi yang baik, karena selama masa pemeriksaan banyak dilakukan wawancara dan 
permintaaan keteranagn dari auditan untuk memperoleh data. Buttery, Hurford, dan Simpson (Audit in the Public Sector,1993) menyebutkan beberapa mutu personal lainnya yang harus dimiliki oleh auditor, seperti kepandaian, perilaku yang baik, komitmen yang tinggi, serta kemampuan imajinasi yang baik untuk menciptakan sikap kreatif dan penuh inovasi.

b. Pengetahuan Umum

Seorang auditor harus memiliki pengetahuan umum untuk memahami entitas yang diaudit dan membantu pelaksanaan audit. Pengetahuan dasar ini meliputi kemampuan untuk melakukan review analitis (analytical review), pengetahuan teori organisasi untuk memahami suatu organisasi, pengetahuan auditing, dan pengetahuan tentang sektor publik. Yang tidak boleh dilupakan adalah pengetahuan akuntansi untuk membantu dalam memahami siklus entitas dan laporan keuangan serta mengelolah data dan angka yang diperiksa.

c. Keahlian Khusus

Keahlian khusus yang dimiliki seorang auditor antara lain keahlian untuk melakukan wawancara, kemampuan mengoperasikan komputer, serta kemampuan menulis dan mempresentasikan laporan dengan baik.

Kompetensi terdiri dari beberapa indikatorindikator yang saling keterkaitan antara satu indikator dengan indikator tinjauan lain, yaitu: (1) Banyaknya pengalaman kerja didalam melakukan audit (2) Interaksi baik dengan klien maupun sesama auditor (3) Pengetahuan yang memadai khususnya dibidang akuntansi audit (4) Memahami SAK dan SPAP yang berlaku sebagai pedoman dalam menjalankan tugasnya sebagai auditor.

Untuk mengenal sikap auditor, wajib terlebih dahulu mengetahui pengertian apa itu sikap dan apa itu auditor. Pengertian sikap adalah evaluatif, terhadap objek, orang atau peristiwa (Robin, 2007), sedangkan pengetian auditor adalah seseorang yang menyatakan pendapat atas kewajaran dalam semua hal yang material, posisi keuangan hasil usaha dan arus kas yang sesuai dengan prinsip akuntansi berlaku umum di Indonesia. (Arens, 1995). Dalam penerapan sikap auditor tertera di dalam SPAP per 1 Januari 2011 yang telah merevisi SPAP tersebut yaitu adanya koifikasi dari SPAP dan Hierarki Standar Auditing yang dilengkapi dengan Kode Profesi Akuntan Publik yang merupakan aturan yang wajib dipenuhi oleh Akuntan Publik.

Dari pengertian di atas dapat disimpulan bahwa pengertian sikap auditor adalah tingkah laku / tanggungjawab evaluatif seseorang terhadap peristiwa yang menyatakan pendapat atas kewajaran laporan keuangan sesuai perinsip akuntansi yang berlaku umum. Sebagai pedoman auditor terdiri dari. (1) Tahap perencanaan. Sebagai suatu pendahuluan mutlak perlu dilakukan agar auditor mengenal benar objek yang akan diperiksa sehingga menghasilkan suatu program audit yang didesain sedemikian rupa agar pelaksanaannya akan berjalan efektif dan efisien. (2) Mengidentifikasikan resiko dan kendali. Tahap ini memastikan bahwa qualified resource sudah dimiliki, dalam hal ini aspek SDM yang berpengalaman dan juga referensi praktik-praktik terbaik. (3) Mengevaluasi kendali dan mengumpulkan bukti-bukti melalui berbagai teknik termasuk survei, interview, observasi, dan review dokumentasi. (4) Mendokumentasikan dan mengumpulkan temuantemuan dan mengidentifikasikan dengan audit. (5) Menyusun laporan. Hal ini mencakup tujuan pemeriksaan, sifat, dan kedalaman pemeriksaan yang dilakukan.

Hasil penelitian Ashton et al. Schwartz dan Soo (dalam Utami, 2006), menemukan bahwa audit delay akan lebih pendek bagi perusahaan yang diaudit oleh KAP yang tergolong besar. Beberapa peneliti membutuhkan kesesuain dengan hipotesis reputasi yang berargumen bahwa KAP besar memiliki insentif lebih besar untuk mengaudit lebih akurat karena mereka memiliki lebih banyak hubungan spesifik dengan klien yang akan hilang jika mereka memberikan laporan yang tidak akurat.

Selain itu karena KAP besar memiliki sumber daya yang lebih besar dibandingkan dengan KAP kecil, sehingga mereka memiliki resiko terancam (exposed) oleh tuntutan hukum pihak ketiga yang lebih besar bila manghasilkan laporan audit yang tidak akurat dan keliru. Hal ini diasumsikan karena KAP besar memiliki karyawan dalam jumlah yang besar, dapat mengaudit lebih efisien dan efektif, memiliki jadwal yang fleksibel sehingga memungkinkannya untuk menyelesaikan audit tepat waktu, dan memiliki dorongan yang lebih kuat untuk menyelesaikan auditnya lebih cepat, guna menjaga reputasinya. Dari keterangan di atas dapat menjelaskan sikap auditor yang terdiri dari beberapa tinjauan-tinjauan berikut:

a. Menggunakan pengetahuan dalam proses pengauditan

b. Tetap teguh pada profesi yang dikerjakan

c. Kepuasan batin dengan memiliki profesi sebagai seorang auditor

d. Profesi auditor penting bagi masyarakat khususnya para pengguna laporan keuangan yang telah diaudit

e. Kerja berdasarkan fakta yang objektif dan relevan untuk menghasilkan suatu laporan audit yang bisa dipertanggungjawabkan kebenarannya 
De Angelo dalam St. Nurmawan (2011) mendefinisikan kualitas audit sebagai kemungkinan bahwa auditor akan menemukan dan melaporkan pelanggaran dalam system akuntansi dengan pengetahuan dan keahlian auditor. Sedangkan pelaporan pelanggaran tergantung kepada dorongan auditor untuk mengungkapkan pelanggaran tersebut. Dorongan ini akan tergantung pada independensi yang dimiliki oleh auditor tersebut.

Dari hal yang dijelaskan di atas maka kualitas audit terdiri dari beberapa tindakan tinjauan-tunjauan berikut yaitu:

a. Klien puas dengan hasil audit

b. Kantor berhasil melakukan audit perusahaan besar

c. Berhati-hati dalam mengambil keputusan

d. Hasil audit dipahami auditee

Gambar 1. Skema Kerangka Pemikiran

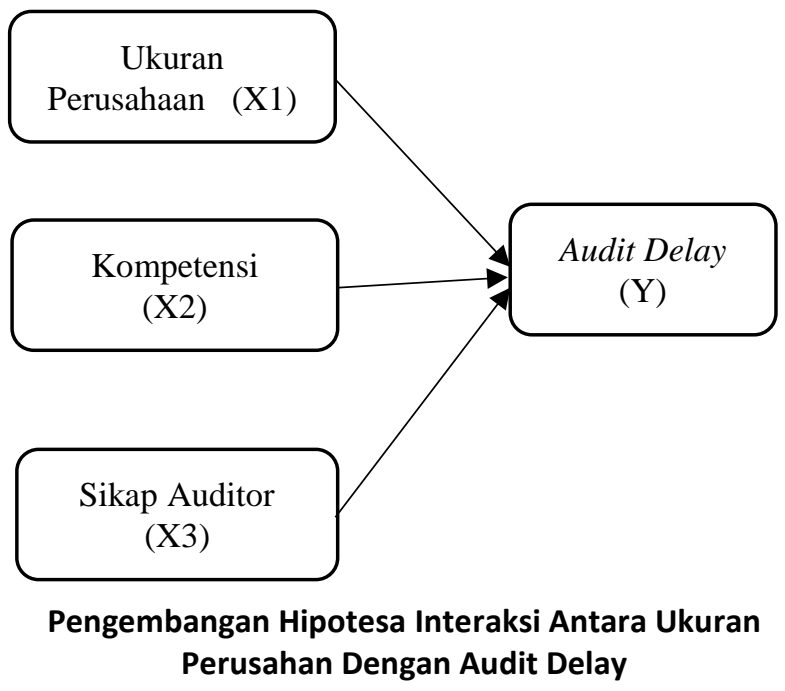

Rachmawati (2008) dalam penelitiannya menyatakan bahwa ukuran perusahaan berpengaruh signifikan terhadap audit delay. Terkait dengan ketepatan waktu laporan keuangan tahunan, ukuran perusahaan juga merupakan fungsi dari kecepatan pelaporan keuangan.

Berdasarkan analisis dan temuan penelitian terdahulu, maka hipotesis penelitian dinyatakan sebagai berikut:

H1: ukuran perusahaan berpengaruh terhadap audit delay.

Interaksi antara kompetensi dengan audit delay

Kompetensi sebagai keahlian seseorang yang berperan secara berkelanjutan yang mana pergerakannya melalui proses pembelajaran dari "mengetahui sesuatu menjadi mengetahi bagaimana" seperti misalnya dari sekedar pengetahuan yang tergantung pada aturan tertentu kepada suatu pertanyaan yang bersifat intutif (Dryfas dan Bambang dalam Feny dan Yohanes, 2012)

Berdasarkan analisis dan temuan penelitian terdahulu, maka hipotesis penelitian dinyatakan sebagai berikut:

$\mathrm{H}$ 2: kompetensi berpengaruh terhadap audit delay.

\section{Interaksi antara sikap auditor dengan audit delay}

Pada umunya sikap auditor harus saling bekerjasama dengan baik dalam sebuah perusahaan yang merupakan penggerak semakin cepatnya laporan keuangan dipublikasikan. Namun semakin tidak baiknya sikap auditor yang malas dan bosan maka semakin molornya laporan keuangan perusahaan untuk dipublikasikan ke publik. Laporan keuangan yang disamping tidak tepatnya waktu mencerminkan ketidakpatuhan perusahaan terhadap peraturan yang ada.

Berdasarkan analisis dan temuan penelitian terdahulu, maka hipotesis penelitian dinyatakan sebagai berikut:

H3: sikap auditor berpengaruh terhadap audit delay.

Interaksi antara ukuran perusahaan, kompetensi, dan sikap auditor terhadap audit delay

Menurut Aryati dan Maria (2005) dalam penelitian terhadap 50 perusahaan go public yang terdaftar di BEJ, menyatakan bahwa ukuran perusahaan yang diukur dengan total assets memiliki pengaruh yang signifikan terhadap audit delay. Subekti (2005) menunjukkan bahwa kantor akuntansi publik internasional atau lebih dikenal dengan Indonesia sebagai the big four membutuhkan waktu yang lebih singkat dalam menyelesaikan audit, karena KAP tersebut dianggap dapat melaksanakan audit secara lebih efisien dan memiliki tingkat fleksibilitas jadwal waktu yang lebih tinggi untuk menyelesaikan audit tepat pada waktunya.

Berdasarkan analisis dan temuan penelitian terdahulu, maka hipotesis penelitian dinyatakan sebagai berikut:

H4: ukuran perusahaan, kompetensi, dan sikap auditor berpengaruh terhadap audit delay.

\section{METODE PENELITIAN}

Penelitian yang dilakukan ini termasuk kedalam penelitian korelasional, dimana metode penelitian ini akan menganalisis dan mengevaluasi kuesioner yang dibagi kepada responden (auditor). Jenis data yang digunakan dalam penelitian ini adalah data primer, data primer adalah data yang diperoleh langsung yang bersumber dari jawaban kuesioner dari responden yang akan dikirim secara langsung kepada auditor dari beberapa KAP di Jakarta. 
Dalam penelitian ini, pengaruh yang diteliti meliputi Ukuran perusahaan atau Size Business diproksikan menjadi perusahaan besar dan perusahaan kecil. Kompetensi atau Competence diproaksikan menjadi keterampilan dan pengetahuan. Selain itu, sikap auditor atau Attitude Auditor yang diproaksikan menjadi tiga sub yakni peran auditor, emosional auditor, dan kejenuhan auditor. Sedangkan
Audit Delay dikembangkan proaksi antara lain keterlambatan kinerja publikasi laporan keuangan.

Operasionalisasi Variabel

Variabel yang digunakan dalam penelitian ini ada dua yaitu: (1) Variable Bebas, meliputi: Ukuran Perusahaan (UP), Kompetensi (K), dan Sikap Auditor (SA), dan (2) Variabel Terikatnya yaitu Audit Delay (AD).

Tabel Profil Responden Penelitian

\begin{tabular}{|c|c|c|c|}
\hline Profil Responden & Katagori & Frekuensi & Presentase \\
\hline \multirow[t]{4}{*}{ Pendidikan Terakhir } & D3 & 6 & $18,75 \%$ \\
\hline & S1 & 23 & $71,88 \%$ \\
\hline & S2 & 3 & $9,38 \%$ \\
\hline & Total & 32 & $100 \%$ \\
\hline \multirow{3}{*}{ Jabatan } & Junior & 20 & $62,50 \%$ \\
\hline & Senior & 12 & $37,50 \%$ \\
\hline & Total & 32 & $100 \%$ \\
\hline \multirow[t]{4}{*}{ Lamanya Bekerja } & $<2$ Tahun & 17 & $53,13 \%$ \\
\hline & $>2$ Tahun & 14 & $43,75 \%$ \\
\hline & Lainnya & 1 & $3,12 \%$ \\
\hline & Total & 32 & $100 \%$ \\
\hline \multirow[t]{4}{*}{ Dari Data Persentase Besarnya Perusahaan } & $<2,44 \%$ & 7 & $21,88 \%$ \\
\hline & $<3,54 \%$ & 21 & $65,63 \%$ \\
\hline & Lainnya & 4 & $12,50 \%$ \\
\hline & Total & 32 & $100 \%$ \\
\hline \multirow[t]{3}{*}{ Dari Data Persentase Kecilnya Perusahaan } & $>3,55 \%$ & 26 & $81,25 \%$ \\
\hline & $>5,74 \%$ & 6 & $18,75 \%$ \\
\hline & Total & 32 & $100 \%$ \\
\hline Dari Data Persentase Ukuran Perusahaan & $<2,44 \%$ & 4 & $12,50 \%$ \\
\hline \multirow[t]{3}{*}{ (Sumber data tambahan) } & $<3,54 \%$ & 13 & $40,63 \%$ \\
\hline & $>3,55 \%$ & 15 & $46,88 \%$ \\
\hline & Total & 32 & $100 \%$ \\
\hline $\begin{array}{l}\text { Dari Data Persentase Ukuran Perusahaan } \\
\end{array}$ & $<2,44 \%$ & 4 & $12,50 \%$ \\
\hline \multirow[t]{3}{*}{ (Sumber data tambahan) } & $<3,54 \%$ & 12 & $37,50 \%$ \\
\hline & $>3,55 \%$ & 16 & $50,00 \%$ \\
\hline & Total & 32 & $100 \%$ \\
\hline $\begin{array}{c}\text { Dari Data Persentase Ukuran Perusahaan } \\
\text { Tahun } 2014\end{array}$ & $<2,44 \%$ & 4 & $12,50 \%$ \\
\hline \multirow[t]{4}{*}{ (Sumber data tambahan) } & $<3,54 \%$ & 8 & $25,00 \%$ \\
\hline & $>3,55 \%$ & 19 & $59,38 \%$ \\
\hline & $>5,74 \%$ & 1 & $3,13 \%$ \\
\hline & Total & 32 & $100 \%$ \\
\hline
\end{tabular}

Jenis data yang digunakan adalah data kualitataif, yaitu hasil kuesioner yang didapat dari survey kepada auditor independen di KAP daerah Jakarta. Sumber data adalah primer berupa opini objek penelitian secara individual dengan metode survey, yaitu dengan mengajukan pertanyaan tertulis melalui kuesioner 
yang dibagikan secara langsung kepada responden dengan adanya data tambahan sebagai pelengkap penganalisahan dan penetapan metode (1) Data Primer yaitu data yang diperoleh dari hasil penyebaran kuesioner yang harus diolah kembali agar data tersebut dapat digunakan dalam penulisan penelitian ini dan dapat dimengerti oleh pembaca. Data primer dalam penelitian ini adalah data dari variabel ukuran perusahaan, kompetensi, sikap auditor, dan audit delay. (2) Data Sekunder yaitu Data yang dijadikan pendukung data perimer. Data ini diperoleh melalui literature yang dimaksudkan untuk memperoleh landasan teori. Sebagai data sekunder dalam penelitian ini adalah ukuran perusahaan dengan menggunakan data dari hasil penelitian terdahulu lalu di analisa dengan metode least square sebagai sarana perbandingan maupun pelengkap dari data yang dibutuhkan.

Sumber data berasal dari jawaban kuesioner yang telah diisi oleh para auditor yang bekerja di 3 Kantor Akuntan Publik (KAP) di Jakarta (tepatnya di Jakarta Selatan) sebagai responden.

Populasi dalam penelitian adalah (KAP) di Jakarta (tepatnya Jakarta Selatan) yang jumlahnya tidak diketahui. Sedangkan sampel yang digunakan dalam penelitian ini sebanyak 32 responden. Penelitian sampel diambil secara acak.

Teknik pengolahan data merupakan tahap yang sangat penting dan menentukan dalam sebuah penelitian. Pada tahap ini data diolah sedemikian rupa sehingga dapat menyimpulkan kebenaran yang dipakai untuk menjawab pertanyaan. Pengukuran variabel-variabel menggunakan instrumen berbentuk pertanyaan tertutup. Instrumen berjumlah beberapa butir pertanyaan yang berhubungan dengan variabel independen yang diteliti serta diukur menggunakan skala Likert dari $1 \mathrm{~s} / \mathrm{d} 5$. Responden diminta memberikan pendapat setiap butir pertanyaan mulai dari sangat tidak setuju sampai sangat setuju.

\section{HASIL DAN PEMBAHASAN}

\section{Statistik Deskripsi}

Analisis hasil perhitungan dari analisis deskriptif persentase untuk tiap variabel tersebut adalah sebagai berikut:

Tabel 2. Statistik Deskriptif

\begin{tabular}{cccccc}
\hline & N & Minimum & Maximum & Mean & Std. Deviation \\
\hline Pendidikan & 32 & 1.00 & 3.00 & 1.9375 & .50402 \\
Jabatan & 32 & 1.00 & 2.00 & 1.3750 & .49187 \\
Lamanya Bekerja & 32 & 1.00 & 3.00 & 1.5000 & .56796 \\
$\quad$ Persentase Besarnya & 32 & 1.00 & 3.00 & 1.9062 & .58802 \\
$\quad$ Perusahaan & & & & & \\
$\quad$ Persentase Kecilnya & 32 & 1.00 & 2.00 & 1.1875 & .39656 \\
$\quad$ Perusahaan & 32 & 1.00 & 3.00 & 2.3437 & .70066 \\
Ukuran Perusahaan 2012 & 32 & 1.00 & 3.00 & 2.3750 & .70711 \\
Ukuran Perusahaan 2013 & 32 & 1.00 & 4.00 & 2.5312 & .76134 \\
Ukuran Perusahaan 2014 & 32 & & & & \\
$\quad$ Valid N (listwise) & & & & &
\end{tabular}

Sumber : Pengolahan Data

\section{Uji Validitas dan Reliabilitas Data}

Berdasarkan uji validitas menggunakan pearson correlation diperoleh hasil bahwa untuk variabel ukuran perusahaan (X1) yang terdiri dari 7 butir pertanyaan dapat dikatakan valid seluruhnya, variabel kompetensi (X2) yang terdiri dari 10 butir pertanyaan seluruhnya dikatakan valid seluruhnya, dan variabel sikap auditor (X3) yang terdiri dari 9 butir pertanyaan seluruhnya dikatakan valid seluruhnya. Demikian juga untuk variabel audit delay (Y) yang terdiri dari 4 butir pertanyaan seluruhnya juga dapat dinyatakan valid. Oleh karena itu seluruhnya butir pertanyaan dapat dilanjutkan sebagai alat atau ukuran dalam penelitian ini. Adapun validitas instrument dapat dilihat pada table berikut: 
Tabel Uji Validitas Variabel

\begin{tabular}{|c|c|c|c|c|}
\hline Variabel & Pertanyaan & r hitung & $r$ tabel & Keputusan \\
\hline \multirow[t]{7}{*}{ Ukuran Perusahaan (X1) } & 1 & 0.895 & 0.3494 & Valid \\
\hline & 2 & 0.642 & 0.3494 & Valid \\
\hline & 3 & 0.856 & 0.3494 & Valid \\
\hline & 4 & 0.597 & 0.3494 & Valid \\
\hline & 5 & 0.800 & 0.3494 & Valid \\
\hline & 6 & 0.722 & 0.3494 & Valid \\
\hline & 7 & 0.766 & 0,3494 & Valid \\
\hline \multirow[t]{10}{*}{ mpetensi (X2) } & 8 & 0.830 & 0.3494 & Valid \\
\hline & 9 & 0.883 & 0.3494 & Valid \\
\hline & 10 & 0.870 & 0.3494 & Valid \\
\hline & 11 & 0.534 & 0.3494 & Valid \\
\hline & 12 & 0.657 & 0.3494 & Valid \\
\hline & 13 & 0.555 & 0.3494 & Valid \\
\hline & 14 & 0.666 & 0.3494 & Valid \\
\hline & 15 & 0.628 & 0.3494 & Valid \\
\hline & 16 & 0.446 & 0,3494 & Valid \\
\hline & 17 & 0.376 & 0,3494 & Valid \\
\hline \multirow[t]{9}{*}{ Sikap Auditor (X3) } & 18 & 0.653 & 0.3494 & Valid \\
\hline & 19 & 0.758 & 0.3494 & Valid \\
\hline & 20 & 0.744 & 0.3494 & Valid \\
\hline & 21 & 0.722 & 0.3494 & Valid \\
\hline & 22 & 0.628 & 0.3494 & Valid \\
\hline & 23 & 0.712 & 0.3494 & Valid \\
\hline & 24 & 0.744 & 0.3494 & Valid \\
\hline & 25 & 0.359 & 0.3494 & Valid \\
\hline & 26 & 0.900 & 0.3494 & Valid \\
\hline \multirow[t]{4}{*}{ Audit Delay (Y) } & 27 & 0.939 & 0.3494 & Valid \\
\hline & 28 & 0.838 & 0.3494 & Valid \\
\hline & 29 & 0.863 & 0.3494 & Valid \\
\hline & 30 & 0.939 & 0.3494 & Valid \\
\hline
\end{tabular}

Sumber : Data diolah

Uji Reliabilitas ini menggunakan metode alpha cronbanch, yang hasilnya masing-asing dapat dilihat pada tabel

Tabel Uji Reliabilitas

\begin{tabular}{ccc}
\hline Variabel & Alpha Cronbanch & Keputusan \\
\hline Ukuran Perusahaan (X1) & 0.870 & Reliabel \\
Kompetensi (X2) & 0.847 & Reliabel \\
Sikap Auditor (X3) & 0.860 & Reliabel \\
Audit Delay (Y) & 0.917 & Sangat Reliabel
\end{tabular}

Sumber : Pengolahan Data

Dari table di atas terlihat bahwa semua variabel bisa dikatakan reliable karena koefisien alpha cronbachnya masing-masing lebih besar dari 0,60. Dengan demikian berdasarkan hasil uji validitas dan uji reliabilitas data, maka data penelitian yang sudah dikumpulkan layak untuk dianalisis.

Hasil Uji Asumsi Klasik 
Sebelum data dianalisis lebih lanjut menggunakan analisis regresi berganda, terlebih dahulu diuji normalitas, uji multikolinearitas dan uji heterokedastisitas.

\section{Uji Normalitas Data}

Uji normalitas data bertujuan untuk menguji apakah dalam model regresi variabel dependen dan independen keduanya mempunyai distribusi normal atau tidak. Uji normalitas data dalam penelitian ini menggunakan Uji Kolmologorov-Smirnov (Uji K-5) dengan ringkasan analisis sebagaimana disajikan pada table berikut ini:

\section{Tabel Uji Normalitas}

Tests of Normality

\begin{tabular}{|l|r|r|r|r|r|r|}
\hline & \multicolumn{3}{|c|}{ Kolmogorou-Smirnor } & \multicolumn{3}{|c|}{ Shapiro-Wilk } \\
\cline { 2 - 7 } & \multicolumn{1}{|c|}{ Statistic } & \multicolumn{1}{c|}{$\mathrm{df}$} & \multicolumn{1}{c|}{ Siq. } & \multicolumn{1}{c|}{ Statistic } & \multicolumn{1}{c|}{$\mathrm{df}$} & \multicolumn{1}{c|}{ Siq. } \\
\hline Ukuran Perusahaan $(X 1)$ & .217 & 32 & .001 & .861 & 32 & .001 \\
Kompetensi $(X 2)$ & .126 & 32 & $.200^{\prime}$ & .961 & 32 & .291 \\
Sikap Auditor (X3) & .230 & 32 & .000 & .935 & 32 & .054 \\
Audit Delay (O) & .257 & 32 & .000 & .828 & 32 & .000 \\
\hline
\end{tabular}

a. Lilliefors Significance Correction

*. This is a lower bound of the true significance.

\section{Sumber : Data diolah}

Berdasarkan table di atas dilihat pada kolom Kolmogorov-Smirnov pada signifikansi ukuran perusahaan (X1) adalah 0,001 <0,05 maka dapat disimpulkan ukuran perusahaan tidak terjadi masalah normalitas sedangkan kompetensi (X2) adalah 0,200 > 0,05 maka dapat disimpulkan kompetensi terjadi masalah normalitas sedangkan sikap auditor 0,000 dan audit delay (Y) adalah 0,000 kurang dari 0,05 maka dapat disimpulan tidak terjadi masalah normalitas.

Uji Multikolinearitas

Tabel 6. Coefficients ${ }^{\mathrm{a}}$

Coefficients ${ }^{\mathrm{s}}$

\begin{tabular}{|c|c|c|c|c|c|c|c|c|c|c|c|}
\hline \multirow[b]{2}{*}{ Madel } & & \multicolumn{2}{|c|}{ Unstandardized Coefficients } & \multirow{2}{*}{$\begin{array}{c}\begin{array}{c}\text { Standardized } \\
\text { Coefficients }\end{array} \\
\text { Beta }\end{array}$} & \multirow[b]{2}{*}{$t$} & \multirow[b]{2}{*}{ Siq. } & \multicolumn{3}{|c|}{ Correlations } & \multicolumn{2}{|c|}{ Collinearity Statistics } \\
\hline & & $B$ & Std. Error & & & & Zero-order & Partial & Part & Tolerance & VIF \\
\hline \multirow[t]{4}{*}{1} & (Constant) & 2.490 & 4.615 & & .540 & .594 & & & & & \\
\hline & Ukuran Perusahaan (X1) & .750 & .089 & .775 & 8.389 & .000 & .867 & .846 & .707 & .832 & 1.202 \\
\hline & Kompetensi $(\chi 2)$ & -.045 & .087 & -.054 & -.511 & .613 & -.315 & -.096 & -.043 & .647 & 1.546 \\
\hline & Sikap Auditor ( $(3)$ & -.183 & .100 & -.205 & -1.818 & .080 & -.549 & -.325 & -.153 & .560 & 1.786 \\
\hline
\end{tabular}

a. Dependent Variable: Audit Delay ( $)$

\section{Sumber : Data diolah}

Berdasarkan hasil table di atas pada kolom collinearity statistic yaitu pada kolom VIF. Nilai VIF untuk ukuran perusahaan (X1) sebesar 1,202, kompetensi (X2) sebesar 1,546, dan sikap auditor (X3) sebesar 1,786. Karena lebih kecil dari $5(<5)$, maka dapat disimpulkan bahwa tidak terjadi masalah multikolinearitas pada model regresi.

\section{Uji Heterokedastisitas}

Gambar 2.Uji Heteroskedastisitas

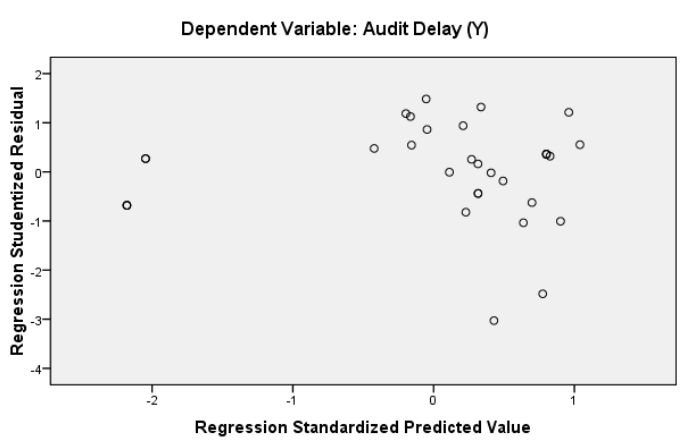

Sumber: Data diolah 
Berdasarkan grafik scatterplot di atas tampak bahwa sebaran data titik-titik menyebar secara acak serta tersebar baik diatas maupun di bawah angka 0 pada sumbu Y. Hal ini dapat disimpulkan bahwa tidak terjadi heteroskedastisitas pada model regresi, sehingga model regresi layak dipakai untuk pengamatan.

\section{Pengujian Hipotesis \\ Uji Regresi Linier Berganda}

Berdasarkan hasil audit regresi berganda didapat koefisien korelasi berganda (R) sebesar 0,895 dengan koefisien determinasinya $\left(\mathrm{R}^{2}\right)$ sebesar 0,801 atau $80,1 \%$.

Tabel

Model Summary

\begin{tabular}{|c|c|c|c|c|c|c|c|c|c|}
\hline \multirow[b]{2}{*}{ Mode } & \multirow[b]{2}{*}{$\mathrm{R}$} & \multirow[b]{2}{*}{ R Square } & \multirow[b]{2}{*}{$\begin{array}{c}\text { Adjusted R } \\
\text { Square }\end{array}$} & \multirow[b]{2}{*}{$\begin{array}{l}\text { Std. Error of } \\
\text { the Estimate }\end{array}$} & \multicolumn{5}{|c|}{ Change Statistics } \\
\hline & & & & & $\begin{array}{l}\text { R Square } \\
\text { Change }\end{array}$ & F Change & df1 & $\mathrm{df} 2$ & Siq. F Change \\
\hline 1 & $.895^{2}$ & .801 & .780 & 1.81010 & .801 & 37.618 & 3 & 28 & .000 \\
\hline
\end{tabular}

a. Predictors: (Constant), Sikap Auditor $(\times 3)$, Ukuran Perusahaan $(\ltimes 1)$, Kompetensi $(\propto 2)$

b. Dependent Variable: Audit Delay ( $)$

Sumber: Pengolahan Data

Adapun untuk koefisien regresinya seperti ditunjukan pada tabel 4.17 berikut:

\section{Hail Uji t (Parsial)}

Uji $\mathrm{t}$ digunakan untuk mengetahui pengaruh masing-masing variabel bebas terhadap variabel terikat yaitu antara ukuran perusahaan terhadap audit delay, kompetensi terhadap audit delay, dan sikap auditor terhadap audit delay. Dari hasil penelitian, didapatkan bahwa koefisien regresi, nilai t dan signifikansi secara parsial.

Uji t masing-masing dapat dilihat pada tabel 4.18 diatas yaitu pada nilai $\mathrm{t}$ dengan nilai $\mathrm{df}=32-2-1=29$ maka nilai $\mathrm{t}$ tabel diperoleh yaitu 1,699. Pada tabel diatas nilai ukuran perusahaan 8,389 > 1,699 maka Ho ditolak, berarti secara parsial ukuran perusahaan berpengaruh signifikan terhadap audit delay. Nilai Kompetensi $-0,511<1,699$ maka Ho diterima, ini berarti secara parsial kompetensi tidak berpengaruh signifikan terhadap audit delay. Sedangkan nilai sikap auditor -1,818<1,699 maka Ho diterima, berarti secara parsial sikap auditor tidak berpengaruh signifikan terhadap audit delay.

\section{Hasil Uji F (Simultan)}

Uji F digunakan untuk mengetahui ada tidaknya pengaruh secara bersama-sama variabel bebas terhadap variabel terikat, yaitu dengan membandingkan $\mathrm{F}$ Hitung dengan $\mathrm{F}$ Tabel dengan tingkat kepercayaan 95\% dan signifikansi 0,05. Dari hasil analisis didapat model regresi berganda sebagai berikut:

Tabel Uji F (Simultan)

ANOVA ${ }^{b}$

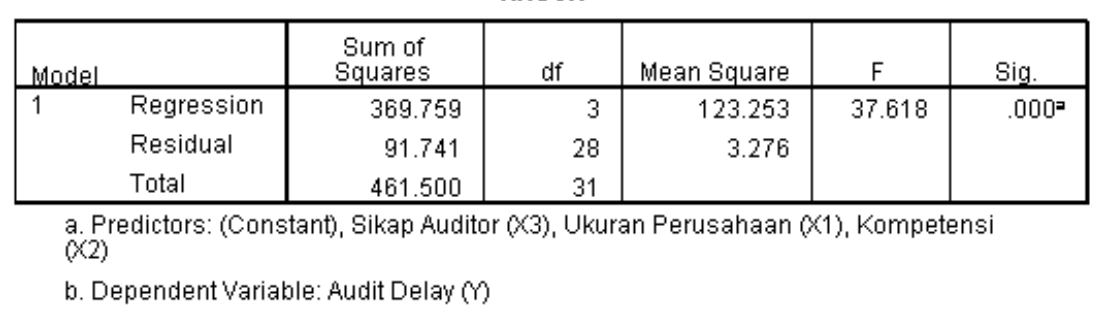

Sumber : Data diolah

Berdasarkan tabel di atas diperoleh $\mathrm{F}$ hitung sebesar 19.575 dengan menggunakan tingkat keyakinan $95 \%$ dan tingkat signifikansi 0,05 df $1=$ variabel $1=3-1=2$ dan df2 (m-k-1) atau 32-2-1=29, hasil diperoleh untuk $\mathrm{F}$ tabel sebesar 3,330. Pada nilai $\mathrm{F}$ hitung $>\mathrm{F}$ tabel $(37,618>3,330)$ maka Ho ditolak artinya ukuran perusahaan, kompetensi dan sikap auditor secara bersama-sama berpengaruh terhadap kualitas audit.

\section{PEMBAHASAN \\ Pengaruh Ukuran Perusahaan Terhadap Audit Delay}

Dari penelitian yang telah dilakukan diperoleh hasil bahwa kompetensi (X1) mempunyai pengaruh yang signifikan terhadap audit delay dilihat nilai 
signifikan 0,000 (lebih kecil dari $\alpha=0,05$ ). Hal ini berarti bahwa audit delay dapat dicapai jika auditor memiliki ukuran perusahaan yang baik. Ukuran perusahaan tersebut terdiri dari sub variabel yaitu besar atau kecil. Auditor sebagai ujung tombak pelaksanaan tugas audit memang harus menilai suatu besaratau kecilnya perusahaan dengan menganalisa lebih lanjut perusahaan tersebut bukan dilihat dan dinilai secara kualitasnya dan tingakat klas besarnya perusahaan.

\section{Pengaruh Kompetensi Terhadap Audit Delay}

Dari penelitian yang telah dilakukan diperoleh hasil bahwa kompetensi (X2) tidak mempunyai pengaruh yang signifikan terhadap audit delay dilihat dari signifikan 0,613 (lebih besar dari $\alpha=0,05$. Hal ini berarti bahwa kualitas audit dapat dicapai dengan menganalisa cara lain seperti selain pengalaman dan pengetahuan. Karena auditor sebagai ujung tombak dalam menganalisa laporan keuangan dalam percepatan pelaporan keuangan kepada publik.

\section{Pengaruh Sikap Auditor Terhadap Audit Delay}

Dari penelitian yang telah dilakukan diperoleh hasil bahwa sikap auditor (X3) yang diproaksikan dengan hubungan terhadap tingkah laku dan attitude tidak berpengaruh signifikan terhadap audit delay, dapat dilihat dari nilai sig. 0,080 (lebih besar dari $\alpha=0.05)$. Hl ini disebabkan sikap mempengaruhi pemikiran dan kebiasaan auditor dalam menyelesaikan laporan yang akan diaudit.

Pengaruh Ukuran Perusahaan, Kompetensi, dan Sikap Auditor Terhadap Audit Delay

Hasil penelitian ini menunjukkan bahwa ukuran perusahaan, kompetensi, dan sikap auditor mempunyai pengaruh terhadap audit delay, dapat dilihat dari nilai signifikan 0,000 (lebih kecil dari $\alpha=0,05$ )

Dari hasil penelitian secara simultan diketahui bahwa audit delay pada laporan keuangan tidak dapat ditentukan oleh faktor ukuran perusahaan, kompetensi,

dan sikap auditor dalam koefisien determinan $\left(\mathrm{R}^{2}\right)$ 0,801 atau $80,1 \%$ adalah dan selebihnya 0,780 atau $78 \%$ ditentukan oleh faktor lain diluar model.

\section{KESIMPULAN}

Berdasarkan hasil pengujian hipotesis, diperoleh kesimpulan. Ukuran perusahaan berpengaruh positif dan signifikan terhadap audit delay. Hasil penelitian ini sesui dengan penelitian sebelumnya yang dilakukan oleh Heru (2012) bahwa ukuran perusahaan berpengaruh positif dan signifikan terhadap audit delay. Kompetensi auditor tidak berpengaruh terhadap audit delay. Hasil penelitian ini berbeda dengan yang sebelumnya dilakukan Ari (2012) dan Feny (2012) bahwa kompetensi berpengaruh secara signifikan terhadap audit delay. Hal tersebut terjadi karena kompetensi memerlukan waktu yang digunakan untuk memahami dan mempelajari setiap tindakan dan kejadian yang akan terjadi sehingga kompetensi tidak berpengaruh signifikan terhadap audit delay. Sikap auditor tidak berpengaruh terhadap audit delay. Hasil ini didapat dari perhitungan yang dilakukan dengan menggunakan SPSS 16 . Oleh karena itu harus dilihat sedemikian rupa apakah sikap auditor berperan penting atau tidak dengan audit delay. Karena sikap auditor tidak berpengaruh terhadap audit delay hal tersebut membuktikan keterlambatan terjadi bukan karena kebiasaan dan tingkah laku auditor terhadap laporan perusahaan sehingga mempengaruhi keterlambatan. Ukuran Perusahaan, Kompetensi, dan Sikap Auditor berpengaruh terhadap audit delay. Hasil penelitian ini sesuai dengan penelitian sebelumnya yang dilakukan Ari (2012) dan Fenny (2012). Berarti dalam hal ini ukuran perusahaan, kompetensi, dan sikap auditor berpengaruh baik secara simultan maupun parsial terhadap audit delay.

\section{REKOMENDASI}

Beberapa saran yang mungkin dapat bermanfaat bagi pemilik maupun pembaca, saran tersebut terdiri dari: (1) Penelitian ini memiliki implikasi bagi auditor yaitu auditor sebaiknya membuat program pemeriksaan agar pemeriksaan dapat berjalan dengan waktu yang lebih cepat, auditor melakukan pemeriksaan secara sistematis, auditor mengumpulkan dan memeriksa berkas-berkas dan data-data sesuai dengan yang dibutuhkan, dan auditor sebaiknya memiliki target waktu pemeriksaan sehingga pelaporan hasil audit dapat disampaikan lebih cepat dan akurat (2) Penelitian ini memiliki implikasi bagi pemerintah atau Bapepam yaitu pemerintah dapat mempertegas peraturan pelaporan audit dari perusahaan kepada pemerintah, memberikan peringatan dan sanksi kepada perusahaan yang sering mengalami keterlambatan pelaporan, dan memberikan imbauan baik kepada auditor dan perusahaan atas peraturan yang berlaku. (3) Penelitian ini memiliki implikasi bagi perusahaan yaitu perusahaan sebaiknya dapat menyediakan datadata yang dibutuhkan auditor dengan lengkap sehingga auditor tidak kesulitan selama pemeriksaan, perusahaan tidak mempersulit auditor selama pemeriksaan laporan keuangan, dan perusahaan memberikan kebebasan dan kebebasan bagi auditor selama pemeriksaan sehingga tidak menimbulkan keterlambatan pelaporan oleh auditor dan terbebas dari sanksi yang ditentukan apabila terjadi keterlambatan pelaporan. 


\section{DAFTAR PUSTAKA}

Agoes, Sukrisno. 2007. “Auditing". Edisi Ketiga, Fakultas Ekonomi Universitas Indonesia, Jakarta.

Ainun Na'im. 1988. "Akuntansi Keuangan I", Yogyakarta, BPFE.

Apriyono, Soemarso. 2008. "Akuntansi Suatu Pengantar", Edisi ke-4, Rineka Cipta, Jakarta.

Arens, Alvin A., Randal J. Elder, Mark S. Beasley. 2010. "Auditing and Assurance Services An Integrated Approach",13th edition, Pearson Education Inc, Upper Saddle River, New Jersey.

Arens, Lobbecke. 1995. Auditing. Terjemahan: Amir Abadi Jusuf Auditing Pendekatan Terpadu. Jakarta, Salemba Empat.

Boynton, William C. Raymond N. Johnson. 2006. "Modern Auditing: Assurance Services and The Integrity of Financial Reporting", 8th edition, John Wiley \& Sons Inc, United States of America. Edisi Terjemahan Jilid 1. Jakarta: Erlangga.

Choo, F. Dan K. T. Trotman. 1991. "The Relationship Between Knowledge Structure and Judgement for Experienced and Inexperianced Auditors". The Accounting Review. Juli. P. 464-485.

De Angelo, L.E. 1891. Auditor Independence, "Low Balling" and Disclose Regulation, dalam Journal of Accounting \& Economics 3 (August): 113127.

Dels, Donald R. dan Gary A. Gtroux. 1992. "Determinants of Audit Quality in Public Sector", The Accounting Review. Juli. P. 462478.

Destiana, Ari. 2012 "Determinan ROA, DER, SIZE, Opini Audit, dan Kualitas Auditor Terhadap Audit Delay yang Terdaftar di BEI 2008-2010". Jurnal Ilmiah Ekonomi UDN.

Feny dan Yohanes. 2012 "Pengaruh Akuntabilitas dan Kompetensi Auditor Terhadap Kualitas Audit (Studi Empiris pada Kantor Akuntan Publik di Semarang", Jurnal Vol. 1 No. 1 Januari.

Ghozali, Imam. 2005. AplikasiAnalisis Multivariative dengan Program SPSS. Semarang: Badan Penerbit Universitas Diponegoro.

Hersugondo dan Andi. 2013 "Prediksi Probabilitas Audit Delay dan Faktor Determinanya", Jurnal Ekonomi dan Manajemen.
Ikatan Akuntan Indonesia. 2012. Standar Akuntansi Keuangan. Jakarta: Salemba Empat

Mulyadi. "Auditing (Pengauditan)". 2002. Buku I Edisi Ke Enam, PT. Salemba Empat.

Kartika, Andi. 2009. "Faktor-Faktor yang Mempengaruhi Audit Delay di Indonesia", Jurnal Bisnis dan Ekonomi, Volume 16, No 1, Hal 1 -7.

Ma'ruf. Muhamad. 2006. "Pengaruh Faktor-Faktor dalam Corporate Governance", Jurnal Bisnis dan Ekonomi USU.

Mina pizza, Shu Lin, and Mark Vargus. 2011. "The Impact of Internal Audit Function Contribution on Audit Delays", E-Jurnal Bussines.

Nur Indriantoro dan Bambang Supeno. 1999. "Metode Penelitian Bisnis", Edisi I, Yogyakarta: BPFE.

Pacter, Paul. 2015. "IFRS as global standards: a pocket guide" IFRS Foundation 30 Cannon Street London EC4M 6XH United Kingdom.

Pindyck, R. S dan D.L. Rubinfield. (1998). "Econometric Models and Economic Forecast", New York: McGraw-Hill International.

Prayogi. 2009. "Faktor-Faktor yang Berpengaruh Terhadap Audit Delay" (Studi Empiris pada Perusahaan Telekomunikasi yang Terdaftar di Bursa Efek Indonesia pada Tahun 20092011)."

Rachmawati, Sistya. 2008. "Pengaruh Faktor Internal dan Eksternal Perusahaan Terhadap Audit Delay dan Timeliness", Jurnal Akuntansi dan Keuangan, Volume 10, No 1 Mei Hal 1-10.

Rochimawati. 2008. "Analisis Diskriminan Audit Delay Pada Industri Keuangan Di Bursa Efek Indonesia (BEI)."

Rustiana, Prabandari, Jeane Deart Meity. 2007. "Beberapa Faktor yang Berdampak pada Perbedaan Audit delay (Studi Empiris pada Perusahaan-Perusahaan keuangan yang terdaftar di BEJ)", Kinerja, Volume 11 , No 1, Hal 27-39.

Setiawan, Heru. 2012. "Pengaruh Ukuran Perusahaan, Reputasi Auditor, Opini Audit, Profitabilitas, dan Solvabilitas Terhadap Audit Delay", Jurnal Ekonomi dan Blsnis UIN.

Silvani dan Made. 2013 "Pengaruh Profitabilitas, Leverage, Kompleksitas Operasional, Reputasi KAP, dan Komite Audit pada Audit Delay", Jurnal Ilmiah Vol. 2 No. 23 Oktober.

Subekti, Imam. 2005 "Faktor-Faktor yang Berpengaruh Terhadap Audit Delay di Indonesia", Jurnal Ekonomi dan Manajemen, Volume 6, No 1 Februari Hal 47-54.

https://id.wikipedia.org/wiki/Sikap 